\title{
RESENSI BUKU
}

Judul : The Biblical Hebrew Companion for Bible Software Users

Penulis : Michael Williams

Penerbit : Grand Rapids: Zondervan

Tahun : 2015

Halaman : 144 pages

Dalam buku ini Michael Williams berupaya menjembatani 2 ekstrem dalam kaitan studi bahasa Ibrani. Ekstrem yang pertama tetap berpendapat bahwa studi bahasa Ibrani dengan pola "lama" yang meliputi penguasaan paradigma, tata bahasa, sintaks dan kosa kata dengan tidak mempedulikan perkembangan teknologi yang dapat mempermudahkan studi bahasa. Ekstrem yang lain sangat bergantung pada teknologi dan mempersamakan mempelajari perangkat lunak (software) Alkitab dengan mempelajari bahasa asli Alkitab. (p. 5)

Buku ini ditujukan bagi mereka yang menggunakan program perangkat lunak Alkitab (Accordance Bible Software, BibleWorks atau Logos Bible Software). Perangkat lunak tersebut memberikan informasi teknis tata bahasa Ibrani, dan buku ini memberikan penjelasan informasi teknis tata bahasa yang sedang diselidiki, sehingga seseorang sungguh mendapatkan manfaat yang maksimal dari perangkat lunak Alkitab yang digunakannya. (p. 7)

Buku ini disusun dengan urutan abjad, sehingga ketika seseorang menggunakan program perangkat lunak Alkitab Ibrani dan menemukan istilah tata bahasa yang ingin diketahui dan dipahami, ia dapat melihat daftar isi dan kemudian menemukan halaman yang membahas hal tersebut. Adapun penjelasan tata bahasa sengaja ditulis hanya 2 halaman, yang meliputi uraian 
bentuk khas yang muncul, uraian singkat tentang fungsinya dan contoh teks Alkitab berserta pemahaman eksegetisnya. Selanjutnya jika seseorang ingin memperdalam lebih lanjut, ia dapat melihatnya dalam bagian akhir buku ini yang berkaitan dengan Select Bibliography for Further Study. (pp. 7-8)

Dalam buku ini terdapat sebuah kesalahan dalam penyebutan sebuah vokal dari kata בִִּ Y. yang dijadikan contoh. Vokal patakh (_) di bawah konsonan $\supseteq$ disebut sebagai qibbuts. (p. 104). Williams tidak hanya memberikan pemahaman eksegetis dari suatu informasi teknis tata bahasa, tetapi juga aplikasi praktisnya, sehingga seseorang dapat menemukan "kekayaan" dari informasi teknis tersebut. Namun kadangkala upaya ini "terlalu bersemangat", sehingga aplikasinya terkesan berlebihan. Hal ini di antaranya nampak dalam pembahasan tentang "energic nun" dalam Ulangan 32 yang mengungkapkan bagaimana Allah begitu menjaga, melindungi, dan menjaga seperti biji mata Allah. Williams mengungkapkan, "Certainly one would expect that God's "energic Nun love" for his people would result in their "energic Nun love" for him! God's emphatic, energetic care and provision for his people would be most fully realized in Christ's incarnation, death, and resurrection on our behalf." (p. 39).

Walaupun Williams memperuntukkan buku ini juga bagi mereka yang tidak pernah belajar formal bahasa Ibrani untuk dapat memperoleh manfaat pemahaman informasi teknis tata bahasa ketika mempergunakan perangkat lunak Alkitab, namun nampaknya tujuan ini sangat sulit tercapai. Pengetahuan dasar bahasa Ibrani dibutuhkan untuk dapat memperoleh manfaat maksimal dari buku ini.

Secara umum buku ini sangat bermanfaat sebagai suatu "pengingat ulang" bagi mereka yang telah mempelajari bahasa 
Ibrani dasar dan menggunakan perangkat lunak Alkitab dalam upaya membaca dan menyelidiki suatu teks bahasa Ibrani. Informasi teknis tata bahasa Ibrani yang ingin diketahui dapat cepat ditemukan dalam buku ini karena disusun secara abjad. Juga adanya uraian yang ringkas, jelas, dan padat tentang informasi teknis tersebut. Sedangkan untuk pemahaman yang lebih mendalam, seseorang tetap membutuhkan buku tata bahasa dan sintaks bahasa Ibrani yang lebih lengkap.

Sia Kok Sin 